\title{
Characterization of Pathogenic Bacteria Isolated from Sudanese Banknotes and Determination of Their Resistance Profile
}

\author{
Noha Ahmed Abd Alfadil $\left(\mathbb{D},{ }^{1}\right.$ Malik Suliman Mohamed $\left(\mathbb{D},{ }^{2}\right.$ Manal M. Ali, ${ }^{3}$ \\ and El Amin Ibrahim El Nima ${ }^{2}$ \\ ${ }^{1}$ Department of Pharmaceutics, Faculty of Pharmacy, University of Al Neelain, Khartoum, Sudan \\ ${ }^{2}$ Department of Pharmaceutics, Faculty of Pharmacy, University of Khartoum, Khartoum, Sudan \\ ${ }^{3}$ Department of Pharmaceutical Microbiology, Faculty of Pharmacy, Omdurman Islamic University, Khartoum, Sudan
}

Correspondence should be addressed to Noha Ahmed Abd Alfadil; noohaabdalfadil90@gmail.com

Received 18 May 2018; Revised 16 July 2018; Accepted 8 August 2018; Published 24 September 2018

Academic Editor: Susana Merino

Copyright (C) 2018 Noha Ahmed Abd Alfadil et al. This is an open access article distributed under the Creative Commons Attribution License, which permits unrestricted use, distribution, and reproduction in any medium, provided the original work is properly cited.

\begin{abstract}
Background. Banknotes are one of the most exchangeable items in communities and always subject to contamination by pathogenic bacteria and hence could serve as vehicle for transmission of infectious diseases. This study was conducted to assess the prevalence of contamination by pathogenic bacteria in Sudanese banknotes, determine the susceptibility of the isolated organisms towards commonly used antibiotics, and detect some antibiotic resistance genes. Methods. This study was carried out using 135 samples of Sudanese banknotes of five different denominations (2, 5, 10, 20, and 50 Sudanese pounds), which were collected randomly from hospitals, food sellers, and transporters in all three districts of Khartoum, Bahri, and Omdurman. Bacterial prevalence was determined using culture-based techniques, and their sensitivity patterns were determined using the Kirby-Bauer disk diffusion method. Genotypic identification was carried out using PCR and 16S rDNA sequencing. Antibiotic resistance genes of some isolates were detected using PCR technique. Results. All Sudanese banknotes were found to be contaminated with pathogenic bacteria. Klebsiella pneumoniae was found to be the most frequent isolate (23\%), whereas Bacillus mycoides (15\%) was the most abundant Gram-positive isolate. There was a significant relationship between the number of isolates and the banknote denomination with $p$ value $<0.05$ (the lower denomination showed higher contamination level). Our study has isolated bacteria that are resistant to penicillins and cephalosporins. Multidrug-resistant strains harboring resistant genes (mecA, blaCTX-M, and blaTEM) were also detected. Conclusion. All studied Sudanese banknotes were contaminated with pathogenic bacteria, including multidrug-resistant strains, and may play a significant role in the transmission of bacterial infections.
\end{abstract}

\section{Introduction}

People in almost all communities exchange money on a daily basis, thus circulating banknotes might play a role as a potential vehicle for the transmission of bacterial infection and multidrug-resistant pathogens especially in immune-compromised people [1-8]. Banknotes may be contaminated during transaction, handling, storage, and upon contact with dirty surfaces. Unhygienic practices such as wetting fingers with saliva prior to money counting can introduce an array of bacteria to the notes $[9,10]$. These routes of transmissions have a great impact on public health in developing countries like Sudan, where the frequency of bacterial infection has been increasing [11]. Although every location has specific endemic bacteria, members of Enterobacteriaceae, Bacillus spp., Staphylococcus spp., Micrococcus spp., and Corynebacterium spp. have been identified as common contaminants isolated from banknotes in different countries [1-3, 6, 12-21]. Moreover, bacteria belonging to the genera Vibrio and Pseudomonas have been isolated from banknotes in developing countries [2, 20]. Furthermore, there is accumulated data highlighting the contamination of banknotes by antibiotic-resistant 
bacteria [3, 13, 22-27]. The widespread occurrence of these bacterial species could lead to outbreaks of infections that might result in high morbidity and mortality with significant economic implications [28-31].

This study aimed at determining the prevalence of pathogenic bacteria in Sudanese banknotes, investigating their resistance profile, and characterizing some antibiotic resistance genes in bacterial chromosomes.

\section{Methods}

2.1. Sample Collection and Transport. Sample collection was done from November 2015 to March 2016. A total of 135 Sudanese banknotes were randomly collected from different sources: hospitals $(f=45)$, food sellers $(f=45)$, and transporters $(f=45)$. Five "mint" brand new notes were collected from the bank before being touched by bankers; these were used as controls. These new banknotes were included in the study to determine whether the banknotes are contaminated from their source or during handling in circulation. The banknotes studied were two, five, ten, twenty, and fifty Sudanese pounds ( $f=27$ for each one of them). Collected notes were categorized according to their physical status as clean $(f=36)$, dirty $(f=69)$, very dirty $(f=30)$, and mint $(f=5)$ and transported in sterile plastic Petri dishes to the microbiological laboratory for bacterial isolation, identification, and antibiotic sensitivity testing.

\subsection{Isolation and Identification of Banknotes Contaminants.}

The banknotes were moistened with sterile distilled water, swabbed on both sides, and swab inoculated onto $5 \%$ blood agar plates, selective and differential media (MacConkey's agar, cetrimide agar, xylose lysine deoxycholate agar, and Mannitol salt agar). Plates were incubated aerobically at $37^{\circ} \mathrm{C}$ for $24 \mathrm{~h}$ and observed for bacterial growth. Pure cultures were prepared by streaking a small amount of cells from a distinct colony on a nutrient agar plate and incubated for $24 \mathrm{~h}$ at $37^{\circ} \mathrm{C}$. Isolated colonies after incubation were pure cultures. Pure cultures were identified based on their colonial morphology, Gram reaction, and biochemical tests including indole production, citrate utilization, urease activity, growth on Kligler iron agar (KIA) fermentation of glucose, lactose, and maltose, motility, oxidase production, starch hydrolysis, catalase production, casein hydrolysis, and the MR-VP test, according to protocols previously described $[32,33]$.

2.3. Antibiotic Susceptibility. Antibiotic susceptibility was determined by Kirby-Bauer disc diffusion technique on Mueller-Hinton agar [32], using 18 antibiotic discs supplied by Hi-Media Laboratories, India. Antibiotics tested correspond to the drugs most commonly used in Khartoum State for the treatment of bacterial infections. The discs used were ampicillin (AMP) $10 \mu \mathrm{g}$, amoxicillin (AMX) $25 \mu \mathrm{g}$, amoxiclav (AMC) $30 \mu \mathrm{g}$, cephalexin (CN) $30 \mu \mathrm{g}$, cefuroxime (CXM) $30 \mu \mathrm{g}$, ceftriaxone (CTR) $30 \mu \mathrm{g}$, ceftazidime (CAZ) $30 \mu \mathrm{g}$, gentamicin (GEN) $10 \mu \mathrm{g}$, amikacin (AK) $30 \mu \mathrm{g}$, co-trimoxazole (COT) $25 \mu \mathrm{g}$, penicillin-G (P)
(10IU), erythromycin (E) $5 \mu \mathrm{g}$, azithromycin (AZM) $15 \mu \mathrm{g}$, ciprofloxacin (CIP) $30 \mu \mathrm{g}$, levofloxacin (LE) $5 \mu \mathrm{g}$, nitrofurantoin (NIT) $200 \mu \mathrm{g}$, chloramphenicol (C) $30 \mu \mathrm{g}$, and meropenem (MEM) $10 \mu \mathrm{g}$. Zone of inhibition size interpretative criteria was according to EUCAST standard (the European Committee on Antimicrobial Susceptibility) [34].

2.4. Chelex Method for Genomic DNA Extraction. Representative samples (61 cultures of 270 isolates) covering all species identified by culture-based techniques were selected for genotyping. Three colonies of each isolate were added to $300 \mu \mathrm{l}(1 \times)$ phosphate buffer solution and genomic DNA was extracted by vortexing the mixture for ten seconds and then centrifuged at $10,000 \mathrm{rpm}$ for five minutes. The supernatant was discarded and the pellet resuspended in $200 \mu \mathrm{l}$ of $6 \%$ Chelex, swirled at moderate speed, and incubated at $56^{\circ} \mathrm{C}$ for thirty minutes. After incubation, it was boiled for fifteen minutes at $100^{\circ} \mathrm{C}$, vortexed for ten seconds, and cooled to room temperature, and the mixture was centrifuged for one minute at $10,000 \mathrm{rpm}$. Finally, the supernatant was transferred into a clean $0.5 \mathrm{ml}$ Eppendorf microfuge tube [35]. The dsDNA and protein concentrations (both in $\mu \mathrm{g} / \mathrm{ml}$ ), ratio of $\mathrm{dsDNA} /$ protein, and purity (in percent) were quantified by GeneQuant (Biochrom Ltd, England) according to the manufacturer's instructions.

2.5. PCR Amplification and Detection of $16 S \mathrm{rDNA}$ and Resistance Genes. Genomic DNA of 61 cultures that exhibited marked resistance patterns toward beta-lactam antibiotics was selected to determine beta-lactamase-producing (BLP) bacterial strains. PCR amplifications of $16 \mathrm{~S}$ rDNAs using universal primers (27F: $5^{\prime}$-AGAGTTTGATCCTGGCTCAG3', 1495R: 5'-CTACGGCTACCTTGTTACGA-3') and three resistance genes (blaTEM, blaCTX-M, and mecA) were done using Maxime PCR PreMix kit (iNtRON Biotechnology). To amplify the genes, $13 \mu \mathrm{l}$ of distilled water and $1 \mu \mathrm{l}$ of forward and reverse primers were added to Eppendorf tube containing $15 \mu \mathrm{l}$ of PreMix (ITRON, Korea), and $5 \mu \mathrm{l}$ of DNA extract was added to each PreMix Eppendorf tubes. The PCR was carried out using conventional thermal cycler. Genomic DNA of 50 bacterial isolates was screened for the presence of blaCTX-M gene using known primers (F: 5'-TTTGCGATGCATACCAGTAA- $3^{\prime}$ and R: $5^{\prime}$-CGATATCGTTGGTGCCATA$\left.3^{\prime}\right)$ [36] and blaTEM genes (F: 5'-ATGAGTATTCAACATTTCCG-3' and R: 5'GTCACAGTTACCAATGCTTA$3^{\prime}$ ) [37], whereas DNA of 11 Staphylococcus aureus and coagulase-negative Staphylococci (CONs) isolates was screened for the presence of mecA genes using primers ( $m e c A$ F: 5'-GTAGAAATGACTGAACGTCCGATGA-3', mecA R: $5^{\prime}$-CCAATTCCACATTGTTTCGGTCTAA-3 ${ }^{\prime}$ ) [38]. PCRs were carried out at starting denaturation temperature of $95^{\circ} \mathrm{C}$ for $5 \mathrm{~min}$, and 35 cycles of denaturation at $95^{\circ} \mathrm{C}$ for $1 \mathrm{~min}$, annealing at $58^{\circ} \mathrm{C}$ for blaTEM, at $60^{\circ} \mathrm{C}$ for blaCTX-M for $1 \mathrm{~min}$, and at $50^{\circ} \mathrm{C}$ for $\mathrm{mec} A$ for $45 \mathrm{sec}$, and extension at $72^{\circ} \mathrm{C}$ for $1 \mathrm{~min}$ with final extension at $72^{\circ} \mathrm{C}$ for $10 \mathrm{~min}$. The intended gene bands were confirmed on gel electrophoresis with the aid of UV transilluminator. 
2.6. Statistical Analysis. Data were analyzed descriptively using SPSS 16.0 software. One-way analysis of variance (ANOVA) was used to determine the associations between variables where $P \leq 0.05$ is statistically significant.

2.7. Sequencing of $16 S$ rDNA and NCBI Accession Numbers. $16 \mathrm{~S}$ rDNA of representative samples of 14 clinically important species identified using culture-based technique was sent to Macrogen company (Seoul, Korea) for further DNA purification and standard sequencing, in order to verify the results of biochemical-based methods for bacterial identification at species level. The obtained sequences with different lengths (bp) were viewed and corrected manually using Finch TV program (http://www.geospiza.com/Products/finch tv. shtml) and compared with similar sequences in the GenBank using BLAST server (http://blast.ncbi.nlm.nih.gov/Blast.cgi) to determine the identity scores to similar sequences in the database. High-quality $16 \mathrm{~S}$ rDNA sequences determined in this study were deposited in NCBI to get accession numbers.

\section{Results}

3.1. Types of Bacterial Contaminants in Banknotes. One hundred forty (135 samples and 5 controls) Sudanese banknotes were examined for bacterial contamination, and all samples were found to be contaminated with different species of bacteria. There was no bacterial growth detected on the control samples collected from Central Bank of Sudan where banknotes are printed $(N=5)$. Two hundred seventy organisms were recovered from the samples. Mixed contamination with both Gram-negative and Grampositive bacteria observed in a high percentage $51.9 \%$ (70/135) of tested notes. Samples strictly contaminated with either Gram-negative or Gram-positive bacteria represented $23.7 \%(32 / 135)$ and $24.4 \%$ (33/135), respectively. One hundred fifty-six Gram-negative bacteria were isolated from Sudanese banknotes. Klebsiella pneumoniae was found to be the most frequent isolate $(23 \%$, $N=31 / 135)$, followed by Pseudomonas stutzeri (15\%, $N=21 / 135)$, Escherichia coli $(12 \%, N=16 / 135)$, Pseudomonas aeruginosa, and Citrobacter freundii sharing the same percentage $(9 \%, N=12 / 135)$; Acinetobacter baumannii and Salmonella paratyphi A sharing the same percentages $(7.4 \%, N=10 / 135)$; Proteus mirabilis $(4.4 \%$, $N=6 / 135)$, Alcaligenes faecalis (3.7\%, N=5/135), Enterobacter cloacae, and Serratia marcescens sharing the same percentages $(3 \%, N=4 / 135)$; and Shigella flexneri $(2.2 \%$, $N=3 / 135)$. Nine different species of $114 \mathrm{Gram}$-positive bacterial contaminants were isolated from Sudanese banknotes, in which Bacillus mycoides were found to be the most abundant $(15 \%, N=21 / 135)$, followed by Bacillus subtilis (14.8\%, $N=20 / 135)$, Bacillus cereus $(12.5 \%$, $N=17 / 135)$, Micrococcus luteus $(10 \%, N=14 / 135)$, Staphylococcus haemolyticus $(8.8 \%, N=12 / 135)$, Staphylococcus aureus, and Staphylococcus saprophyticus having the same percentage $(8.1 \%, N=11 / 135)$, Bacillus horikoshii $(3.7 \%$, $N=5 / 135)$ and Staphylococcus epidermis $(2.2 \%, N=3 / 135)$.
Out of 270 bacterial isolates obtained from banknotes, 61 were subjected to $16 \mathrm{~S}$ rDNA amplification using universal primers. Fourteen of them were confirmed using $16 \mathrm{~S}$ rDNA sequencing methods in order to verify the results of phenotyping for bacterial identification at species level. Nucleotide BLAST search gave $99-100 \%$ identity score to the sequences in the database. The comparison between the conventional identification and the $16 \mathrm{~S}$ rDNA sequence identification showed same results for both methodologies the 14 bacterial isolates selected. These isolates have been registered in GenBank under accession numbers (Klebsiella pneumoniae (KY049979), Klebsiella oxytoca (KY031321), Escherichia coli (MG198700), Pseudomonas aeruginosa (MG198702), Citrobacter freundii (MG198698), Acinetobacter baumannii (KY114514), Alcaligenes faecalis (MG198707), Enterobacter cloacae (KY205640), Bacillus horikoshii (MG198701), Staphylococcus aureus (KY176381), Staphylococcus haemolyticus (MG198699), Proteus mirabilis (JF947362), Bacillus cereus (JX218990.1), and Shigella flexneri (KY199565)).

3.2. Relationship between Bacterial Contamination and Denomination of Banknotes. There was a significant relationship between the number of isolates and banknote denomination with $p$ value $<0.05$. The lower denomination 2 and 5 Sudanese Pounds showed higher contamination level with mixed species of bacteria (by 63\% for both) than higher denomination 10, 20, and 50 Sudanese Pounds (by $37 \%, 51 \%$, and $44.5 \%$, respectively).

3.3. Relationship between Bacterial Contamination and Physical State of Banknotes. Out of 135 of collected notes, 69 (51\%) were dirty, 36 (27\%) were clean, and 30 (22\%) were very dirty.

There was a no significant relationship between the number of isolates and the physical appearance of banknotes ( $p$ value $<0.05$ ). Contamination by mixed species of bacteria was observed with high percentages in clean, very dirty, and dirty banknotes by $58 \%(21 / 36), 50 \%$ (15/30), and $49 \%$ (34/69), respectively. The prevalence of Gram-negative bacteria was high in clean (27.8\%) and dirty $(30.4 \%)$ notes as opposed to the recovery in very dirty notes in which Gram-positive bacteria were more abundant (30\%) compared to Gram-negative bacteria.

\subsection{Relationship between Bacterial Contamination and Place} of Banknote Collection. There was no significant relationship between the type of bacteria contaminating and source of banknotes $(p>0.05)$. Contamination by Gram-negative bacteria in Bahri $(N=45)$ was $33.3 \%$. This was more than the $24.4 \%$ contamination by Gram-positive bacteria. However, notes from Omdurman and Khartoum $(N=45)$ had similar frequencies of occurrence of bacteria, in which Gram-positive bacteria in Khartoum (26.7\%) and Omdurman $(22.2 \%)$ were more prevalent than Gram-negative bacteria, $17.8 \%$ and $20.0 \%$, respectively. 
3.5. Antibiotic Resistance Testing: Correlation between Results of Phenotypic and Genotypic Testing. Co-trimoxazole, quinolones (ciprofloxacin and levofloxacin), and meropenem were the most active drugs as they were effective against all isolates (100\%). All examined isolates recovered from Sudanese banknotes were resistant to ampicillin (100\%). However, some strains of Proteus mirabilis, Serratia marcescens, Citrobacter freundii, and K. oxytoca were found to be sensitive to amoxicillin and co-amoxiclav. Out of 61 genomic DNA subjected to antibacterial resistance analysis, 24 harbored the resistance genes; blaCTX-M gene was detected in PCR products of E. coli, K. pneumoniae, Enterobacter cloacae, Acinetobacter baumannii, and $P$. aeruginosa. However, blaTEM gene was detected in one strain of E. coli. Isolates of $S$. aureus and CONS harboring $M e c A$ gene in their chromosomes were also detected as shown in Tables 1 and 2 .

\section{Discussion}

In this study, it was found that all examined Sudanese banknotes $(100 \%(N=135))$ were contaminated with different species of bacteria. The first occurrence of bacteria in banknotes was reported by Pope and co-workers in 2000 [4]. Successive studies conducted on Indian rupee $[2,25]$, Bangladeshi taka [8], Iraqi notes [19], and Ghanaian notes [5] reported that banknotes were contaminated (100\%) with pathogenic bacteria, which were similar to our findings from Sudanese banknotes. The contamination of Saudi [3] and Nepali [12] paper notes with pathogenic bacteria was found to be $98 \%$ and $75 \%$, respectively.

Gram-negative bacteria observed in our study belonged to Enterobacteriaceae and Pseudomonas spp. They were more prevalent than Gram-positive organisms. K. pneumoniae was the most frequent Gram-negative isolate, while Bacillus spp. was the most abundant Gram-positive isolate. Different species of bacteria isolated in this study were very similar to those isolated in previous studies [8, 18, 39, 40]; however, studies carried out in Saudi Arabia [3], Pakistan [26], Ghana [5], India [25], Iraq [19], and France [13] established Gram-positive bacteria as the major isolates from the contaminated banknotes.

This study sorted out the diversity of bacterial distribution in Khartoum, Bahri, and Omdurman. We found that bacterial contaminations were most abundant in Omdurman. Some species like Acinetobacter baumannii and Alcaligenes faecalis recovered from examined notes were not reported among Sudanese notes contaminants in the previous study which was conducted in the same study sites [18]. These differences in bacterial patterns may be attributed to regional variation of bacterial profiles and habits of the local people $[12,27]$. Temporal variation in profiles should be another explanation for the variation observed. Furthermore, presence of the genera of coliform bacilli such as Escherichia, Klebsiella, and Salmonella is suggestive of significant fecal contamination of banknotes that may reflect the poor local sanitation and personal hygiene. They might also signify a potential minefield for nosocomial infections.
Detection of Bacillus spp. in this study agreed with findings from Ghana and India [10, 21]. The ubiquitous nature of the Bacillus spp., greater colonization ability, and the ability of its spores to resist environmental changes might help it to inhabit the banknotes.

The extent of bacterial contamination was found to be related to banknote denomination $(p<0.05)$, in which the lower denominations show higher levels of contamination especially by mixed Gram-positive and Gram-negative bacteria. In this context, these findings are consistent with recent reports $[2,8,13,17-20,25,26,39]$. Lower denominations have higher circulation rate, therefore increasing the possibility of mishandling compared with higher denomination.

It is worth noting that bacterial growth was not detected in 5 samples of mint "newly printed" banknotes. The lack of growth in these notes might be attributed to the fact that they had not been in circulation that exposed them to usage and handling. However, some researchers believed that uncirculated notes are contaminated with fastidious organisms and the media or culture conditions employed were inappropriate for their isolation [13].

Bacteria isolated in this project were subjected to conventional Kirby-Bauer disk diffusion technique to test their sensitivity patterns towards some antimicrobials. All bacteria recovered from Sudanese banknotes were resistant to penicillins except some strains of Proteus mirabilis, Serratia marcescens, and K. oxytoca. Furthermore, some strains of K. oxytoca, Serratia marcescens, and coagulase negative Staphylococci were found to be resistant to cephalosporins. In this study, notable multidrug-resistant $P$. aeruginosa, Escherichia coli, and Klebsiella spp. were isolated. Moreover, Staphylococcus aureus showed significant resistance to macrolides (erythromycin and azithromycin). mecA was detected in all isolates of $S$. aureus and some strains of CONs isolates that exhibited resistance to penicillins, as shown in Tables 1 and 2 .

It is known that infection by multidrug-resistant bacteria limit therapeutic options and subsequently facilitate the dissemination of these strains. The sensitivity patterns of isolates to antibiotics are harmonious with the patterns reported by Akoachere et al. [13], except co-trimoxazole which was inactive against their isolates. The resistance of isolates to penicillins was comparable to that reported by Ali et al. [26]. This can be explained by the regional variation of organisms and is directly proportional to the use and misuse of antibiotics in the community.

Increasing resistance to penicillins and third-generation cephalosporins by high prevalence of ESBL among members of Enterobacteriaceae has become a serious cause of nosocomial infections leading to treatment failure and consequent escalation in costs of hospitalization. Resistance to penicillins and cephalosporins was also confirmed genotypically by detecting the presence of blaTEM- and blaCTX-M-resistant genes with PCR. blaCTX-M gene was detected in the PCR products when E. coli, K. pneumoniae, Enterobacter cloacae, Acinetobacter baumannii, and $P$. aeruginosa chromosomes used as PCR templates, but was found to be absent in other bacteria, that might contradict their disk diffusion results. 
TABLE 1: Resistance profile and resistance genes (blaTEM, blaCTX-M, or mecA) detected in pathogenic bacteria isolated from banknotes $(N=61)$.

\begin{tabular}{|c|c|c|}
\hline Isolates & "Resistance profile" & "Resistance genes" \\
\hline \multicolumn{3}{|l|}{ Gram-negative isolates $(N=49)$} \\
\hline E. coli (5 isolates) & $\begin{array}{c}(\mathrm{AMP}),(\mathrm{AMX}),(\mathrm{AMC}),(\mathrm{CN}), \mathrm{CXM}),(\mathrm{CTR}),(\mathrm{CAZ}), \\
\text { and (NIT) }\end{array}$ & blaTEM and blaCTX-M (1\5), (5\5) \\
\hline Proteus mirabilis (1 isolate) & (AMP), (AMX), (AMC), (CN), (CXM), (CTR), and (CAZ) & $-(1 \backslash 1)$ \\
\hline Serratia marcescens (4 isolates) & (AMP), (AMX), (AMC), (CN), (CXM), (CTR), (CAZ) & $-(4 \backslash 4)$ \\
\hline$P$. aeruginosa (5 isolates) & $(\mathrm{GEN})$ and $(\mathrm{AK})$ & blaCTX-M $(1 \backslash 5)$ \\
\hline P. stutzeri (14 isolates) & - & $-(14 \backslash 14)$ \\
\hline K. oxytoca (1 isolate) & $(\mathrm{AMP}),(\mathrm{AMX}),(\mathrm{AMC}),(\mathrm{C})$, and $(\mathrm{AK})$ & $-(1 \backslash 1)$ \\
\hline Acinetobacter baumannii (3 isolates) & - & blaCTX-M (2\3) \\
\hline Salmonella paratyphi A (2 isolates) & $(\mathrm{AMP}),(\mathrm{AMX}),(\mathrm{AMC}),(\mathrm{CN})$, and $(\mathrm{NIT})$ & $-(2 \backslash 2)$ \\
\hline K. pneumoniae (6 isolates) & (AMP), (AMX), (AMC), (CTR), and (AK) & blaCTX-M (5\6) \\
\hline Enterobacter cloacae (2 isolates) & $(\mathrm{AMP}),(\mathrm{AMX}),(\mathrm{AMC}),(\mathrm{CXM})$, and $(\mathrm{CTR})$ & blaCTX-M (2\2) \\
\hline Shigella flexneri (1 isolate) & (AMP), (AMX), (AMC), and (NIT) & $-(1 \backslash 1)$ \\
\hline Alcaligenes faecalis (3 isolates) & $(\mathrm{AMP}),(\mathrm{AMX}),(\mathrm{CXM})$, and $(\mathrm{Ak})$ & $-(3 \backslash 3)$ \\
\hline Citrobacter freundii (2 isolates) & $(\mathrm{AMP}),(\mathrm{AMX}),(\mathrm{AK})$, and $(\mathrm{NIT})$ & $-(2 \backslash 2)$ \\
\hline \multicolumn{3}{|l|}{ Gram-positive isolates $(N=12)$} \\
\hline S. aureus (6 isolates) & $\begin{array}{c}(\mathrm{AMP}),(\mathrm{P}),(\mathrm{AMX}),(\mathrm{AMC}),(\mathrm{CN}),(\mathrm{CXM}),(\mathrm{AZM}),(\mathrm{E}), \\
\text { and }(\mathrm{C})\end{array}$ & $\operatorname{mec} A(6 \backslash 6)$ \\
\hline CONS (6 isolates) & $(\mathrm{AMP}),(\mathrm{P}),(\mathrm{AMX})$, and $(\mathrm{CXM})$ & $m e c A(2 \backslash 6)$ \\
\hline
\end{tabular}

TABLE 2: Percentage resistance to each relevant antibiotic among all isolated Gram-negative and Gram-positive bacteria $(N=61)$.

\begin{tabular}{lc}
\hline Antibiotics & Percentage resistance \\
\hline (1) Ampicillin (AMP) $10 \mu \mathrm{g}$ & $(61) 100 \%$ \\
(2) Amoxicillin (AMX) $25 \mu \mathrm{g}$ & $(39) 64 \%$ \\
(3) Amoxiclav (AMC) $30 \mu \mathrm{g}$ & $(27) 44 \%$ \\
(4) Cefuroxime (CXM) $30 \mu \mathrm{g}$ & $(18) 30 \%$ \\
(5) Cephalexin (CN) $30 \mu \mathrm{g}$ & $(17) 28 \%$ \\
(6) Nitrofurantoin (NIT) $200 \mu \mathrm{g}$ & $(8) 13 \%$ \\
(7) Ceftriaxone (CTR) $30 \mu \mathrm{g}$ & $(8) 13 \%$ \\
(8) Ceftazidime (CAZ) $30 \mu \mathrm{g}$ & $(6) 10 \%$ \\
(9) Amikacin (AK) 30 $\mu \mathrm{g}$ & $(6) 10 \%$ \\
(10) Gentamicin (GEN) $10 \mu \mathrm{g}$ & $(2) 3 \%$ \\
(11) Chloramphenicol (C) $30 \mu \mathrm{g}$ & $(1) 2 \%$ \\
(12) Ciprofloxacin (CIP) $30 \mu \mathrm{g}$ & $(0) 0 \%$ \\
(13) Levofloxacin (LE) $5 \mu \mathrm{g}$ & $(0) 0 \%$ \\
(14) Co-trimoxazole (COT) $25 \mu \mathrm{g}$ & $(0) 0 \%$ \\
(15) Meropenem (MEM) $10 \mu \mathrm{g}$ & $(0) 0 \%$ \\
(16) Penicillin-G (P) (10IU) & $12^{\mathrm{G}}(100 \%)$ \\
(17) Erythromycin (E) $5 \mu \mathrm{g}$ & $5^{\mathrm{G}}(42 \%)$ \\
(18) Azithromycin (AZM) $15 \mu \mathrm{g}$ & $4^{\mathrm{G}}(33 \%)$ \\
\hline
\end{tabular}

G: percentage resistance of examined Gram-positive bacteria isolates $(N=12)$.

Despite some isolates resistance to some beta-lactams, their relevant resistance genes (blaTEM) were not detected in this study, except in one strain of E. coli. Primer dimers or presence of ESBL genes in plasmid may explain the absence of blaTEM-1 in the PCR products. In addition, improper storage of primers and probes may cause them to degrade and lose specificity, which in turn affects the reaction efficiency [28]. It is assumed that if primers were relevant and genes were present in chromosomal material, the difference that might be observed in detection of ESBL-positive isolates by genotypic and phenotypic methods may be justified by the lower sensitivity of phenotypic methods and the influence of environmental factors on the incidence of resistance [37].

The detection of bacterial contamination in banknotes from all sources is a great concern and indicates that contaminated banknotes could pose a health threat particularly to immunocompromised individuals in hospitals or community level. Strategies to reduce the contamination of banknotes are recommended, and such strategies could include the use of plastic banknotes, which can be washed easily, using electronic ATM cards, raising the general awareness of people about the proper handling of banknotes as well as regular withdrawal of damaged notes by federal authorities. Finally, periodical screening for the patterns of antibiotics resistance in environmental bacteria using large sample size is highly recommended.

\section{Conclusion}

Sudanese banknotes are contaminated with pathogenic and potentially pathogenic bacteria. This contamination may play a significant role in the transmission of infections in Sudan. Also, this study revealed that multidrug-resistant strains of different isolates were prevalent in some Sudanese banknotes.

\section{Data Availability}

"Sequences data" that support the findings of this study have been deposited in "GenBank" under accession numbers (Klebsiella pneumoniae (KY049979), Klebsiella oxytoca (KY031321), Escherichia coli (MG198700), Pseudomonas aeruginosa (MG198702), Citrobacter freundii (MG198698), Acinetobacter baumannii (KY114514), Alcaligenes faecalis (MG198707), Enterobacter cloacae (KY205640), Bacillus horikoshii (MG198701), Staphylococcus aureus (KY176381), Staphylococcus haemolyticus (MG198699), Proteus mirabilis 
(JF947362), Bacillus cereus (JX218990.1), and Shigella flexneri (KY199565)).

\section{Conflicts of Interest}

The authors declare that they have no conflicts of interest.

\section{Authors' Contributions}

Noha Ahmed Abd Alfadil participated in designing the study, performed all parts of the experiments incorporated in this manuscript, and wrote the manuscript. Malik Suliman Mohamed supervised all parts of the experiments, participated in designing the study, contributed to data analysis and interpretation, and also contributed to the writing process. Manal M. Ali supervised bacteria isolates identification in Laboratory. El Amin Ibrahim El Nima participated in the planning of the study and contributed to the writing process. All authors have read and approved the final manuscript.

\section{Acknowledgments}

We are grateful to Mohamed Salih Hassan, Hisham N Altayb, SalahEldin G Elzaki, and Abdalla M. khalid for the unlimited help and support during our project.

\section{References}

[1] F. M. S. E.-D. El-Dars and W. M. H. Hassan, "A preliminary bacterial study of Egyptian paper money," International Journal of Environmental Health Research, vol. 15, no. 3, pp. 235-240, 2005.

[2] S. Thiruvengadam, K. S. Shreenidhi, H. Vidhyalakshmi et al., "A study of bacterial profiling on coins and currencies under circulation and identifying the virulence gene in Chennai (TN)," International Journal of ChemTech Research, vol. 6, no. 9, pp. 4108-4114, 2014.

[3] S. S. Alwaheel and A. N. Laila, "Bacterial and fungal contamination of Saudi Arabian paper currency and cell phones," Asian Journal of Biological Sciences, vol. 4, no. 7, pp. 556-562, 2011.

[4] T. W. Pope, P. T. Ender, W. K. Woelk, M. A. Koroscil, and T. M. Koroscil, "Bacterial contamination of Iranian paper currency," Southern Medical Journal, vol. 95, no. 12, pp. 1408-1410, 2002.

[5] P. Feglo and M. Nkansah, "Bacterial load on Ghanaian currency notes," African Journal of Microbiology Research, vol. 4, no. 22, pp. 2375-2380, 2010.

[6] S. K. Barolia, S. Verma, and B. K. Verma, "Coliform contamination on different paper currency in Ajmer, Rajasthan, India," Universal Journal of Environmental Research and Technology, vol. 1, no. 4, pp. 552-556, 2011.

[7] A. Hassan, H. Farouk, F. Hassanein, and R. Abdul-Ghani, "Currency as a potential environmental vehicle for transmitting parasites among food-related workers in Alexandria, Egypt," Transactions of the Royal Society of Tropical Medicine and Hygiene, vol. 105, no. 9, pp. 519-524, 2011.

[8] S. U. Ahmed, S. Parveen, T. Nasreen, and B. Feroza, "Evaluation of the microbial contamination of Bangladesh paper currency notes (Taka) in circulation," Advances in Biological Research, vol. 4, pp. 266-271, 2010.
[9] S. C. Enemuor, P. I. Victor, and O. O. Oguntibeju, "Microbial contamination of currency counting machines and counting room environment in selected commercial banks," Scientific Research and Essays, vol. 7, no. 14, pp. 1508-1511, 2012.

[10] H. Gedik, T. A. Voss, and A. Voss, "Money and transmission of bacteria," Antimicrobial Resistance and Infection Control, vol. 2, no. 1, p. 22, 2013.

[11] A. Saeed, H. Abd, and G. Sandstrom, "Microbial aetiology of acute diarrhoea in children under five years of age in Khartoum, Sudan," Journal of Medical Microbiology, vol. 64, pp. 432-437, 2015.

[12] J. Lamichhane, S. Adhikary, P. Gautam, R. Maharjan, and B. Dhakal, "Risk of handling paper currency in circulation chances of potential bacterial transmittance," Nepal Journal of Science and Technology, vol. 10, pp. 161-166, 2009.

[13] J.-F. T. Akoachere, N. Gaelle, H. Dilonga, and T. K. NkuoAkenji, "Public health implications of contamination of Franc CFA (XAF) circulating in Buea (Cameroon) with drug resistant pathogens," BMC Research Notes, vol. 7, no. 1, p. 16, 2014.

[14] E. Angelakis, E. I. Azhar, F. Bibi et al., "Paper money and coins as potential vectors of transmissible disease," Future Microbiology, vol. 9, no. 2, pp. 249-261, 2014.

[15] T. A. P. Da Fonseca, R. Pessôa, and S. S. Sanabani, "Molecular analysis of bacterial microbiota on Brazilian currency note surfaces," International Journal of Environmental Research and Public Health, vol. 12, no. 10, pp. 13276-13288, 2015.

[16] G. Girma, T. Ketema, and K. Bacha, "Microbial load and safety of paper currencies from some food vendors in Jimma Town, Southwest Ethiopia," BMC Research Notes, vol. 7, no. 1, p. 843, 2014.

[17] R. Neel, "Isolation of pathogenic microorganisms from contaminated paper currency notes in circulation from different market places in Korogwe and Mombo towns in Tanzania," Journal of Microbiology and Biotechnology Research, vol. 2, no. 3, pp. 470-474, 2012.

[18] M. Saadabi A, L. F. Ali, A. B. Omer, G. A. Ahmed, and R. K. A. L. Asa, "Isolation and identification of pathogenic bacteria and fungi from some Sudanase banknote currency," Research Journal of Medical Sciences, vol. 4, no. 5, pp. 315-318, 2010.

[19] S. M. Abdulla, "Isolation and identification of causative agents from some Iraqi Banknote currency. Ibn Al-Haitham," Journal of Pure and Applied Science, vol. 26, no. 1, pp. 75-81, 2013.

[20] S. Sabahat and R. Humaira, "Evaluation of bacterial contamination of Pakistani paper currency notes (rupee) in circulation," European Journal of Biological Research, vol. 3, pp. 94-98, 2011.

[21] M. H. Moosavy, N. Shavisi, K. Warriner, and E. Mosta-Favi, "Bacterial contamination of Iranian paper currency," Iranian Journal of Public Health, vol. 42, no. 9, pp. 1067-1070, 2013.

[22] A. A. Ayandele and S. A. Adeniyi, "Prevalence and antimicrobial resistance pattern of microorganisms isolated from Naira notes in Ogbomoso North, Nigeria," Journal of Research in Biology, vol. 8, pp. 587-593, 2011.

[23] R. Neel, "Multidrug resistance of isolates of methicillin resistant Staphylococcus aureus (MRSA) in paper currency notes from restaurants and hotels in Lusaka in Zambia," International Journal of Pharmacy and Pharmaceutical Sciences, vol. 5, no. 1, pp. 363-366, 2013.

[24] R. B. Rote, N. G. Deogade, and M. Kawale, "Isolation, characterization and antibiotic sensitivity of organism from 
Indian currency," Asiatic Journal of Biotechnology Resources, vol. 3, pp. 255-260, 2010.

[25] K. Pal, N. S. Das, and S. Bhattacharya, "Bacteriological profile of Indian currency circulating in a tertiary care hospital in rural Bengal," Indian Journal of Research and Reports in Medical Sciences, vol. 3, no. 2, pp. 23-27, 2013.

[26] R. Ali, S. Z. Abbas, Z. Hussain, K. Hussain, A. Hayat, and A. Khan, "Bacteriological analysis and antibiogram of Pakistani paper currency notes in circulation in Karachi, Sindh, Pakistan," International Journal of Scientific Research in Environmental Sciences, vol. 3, no. 10, pp. 370-376, 2015.

[27] E. O. Igumbor, C. L. Obi, P. O. Bessong, N. Potgieter, and T. C. Mkasi, "Microbiological analysis of banknotes circulating in the Venda region of Limpopo province, South Africa," South African Journal of Science, vol. 103, no. 9, pp. 365-366, 2007.

[28] M. I. Morosini, R. Canton, J. Martinez-Beltran et al., "New extended-spectrum TEM-type B-lactamase from Salmonella enterica subsp. enterica isolated in a nosocomial outbreak," Antimicrobial Agents and Chemotherapy, vol. 39, no. 2, pp. $458-461,1995$.

[29] A. Breves, C. A. C. Miranda, C. Flores, I. De Filippis, and M. M. Clementino, "Methicillin- and vancomycin-resistant Staphylococcus aureus in health care workers and medical devices," Jornal Brasileiro de Patologia e Medicina Laboratorial, vol. 51, no. 3, pp. 143-152, 2015.

[30] E. Anago, L. Ayi-Fanou, C. D. Akpovi et al., "Antibiotic resistance and genotype of beta-lactamase producing Escherichia coli in nosocomial infections in Cotonou, Benin," Annals of Clinical Microbiology and Antimicrobials, vol. 14, no. 1, p. 5, 2015.

[31] S. Shaikh, J. Fatima, S. Shakil, S. M. D. Rizvi, and M. A. Kamal, "Antibiotic resistance and extended spectrum betalactamases: types, epidemiology and treatment," Saudi Journal of Biological Sciences, vol. 22, no. 1, pp. 90-101, 2015.

[32] B. A. Forbes, D. F. Sahm, and A. S. Weissfeld, Bailey \& Scott's Diagnostic Microbiology, Elsevier, Inc., St. Louis, MO, USA, 12th edition, 2007.

[33] M. Cheesbrough, District Laboratory Practice in Tropical Countries, University, Cambridge, UK, 2000.

[34] EUCAST, European Committee on Antimicrobial Susceptibility Testing Breakpoint Tables for Interpretation of MICs and Zone Diameters European Committee on Antimicrobial Susceptibility Testing Breakpoint Tables for Interpretation of MICs and Zone Diameters, 2015, http://www.eucast.org/fileadmin/ src/media/PDFs/EUCAST_files/Breakpoint_tables/v_5.0_ Breakpoint_Table_01.pdf.

[35] G. Giraffa, L. Rossetti, and E. Neviani, "An evaluation of chelex-based DNA purification protocols for the typing of lactic acid bacteria," Journal of Microbiological Methods, vol. 42, no. 2, pp. 175-184, 2000.

[36] M. Edelstein, M. Pimkin, I. Palagin, I. Edelstein, and L. Stratchounski, "Prevalence and molecular epidemiology of CTX-M extended-spectrum beta-lactamase-producing Escherichia coli and Klebsiella pneumoniae in Russian hospitals," Antimicrobial Agents and Chemotherapy, vol. 47, no. 12, pp. 3724-3732, 2003.

[37] M. Yazdi, A. Nazemi, M. Mirinargasi, M. Jafarpour, S. H. Sharifi, and T. Branch, "Genotypic versus phenotypic methods to detect Extended-Spectrum Beta- Lactamases (ESBLs) in Uropathogenic Escherichia coli," Annals of Biological Research, vol. 3, no. 5, pp. 2454-2458, 2012.

[38] D. J. Geha, J. R. Uhl, C. A. Gustaferro, and D. H. Persingl, "Multiplex PCR for identification of methicillin-resistant
Staphylococci in the clinical laboratory," Journal of Clinical Microbiology, vol. 32, no. 7, pp. 1768-1772, 1994.

[39] E. U. Umeh, J. U. Juluku, and T. Ichor, "Microbial contamination of "Naira" (Nigerian currency) notes in circulation," Research Journal of Environmental Sciences, vol. 1, no. 6, pp. 336-339, 2007.

[40] C. C. C. R. De Carvalho and M. J. Caramujo, "Bacterial diversity assessed by cultivation-based techniques shows predominance of Staphylococccus species on coins collected in Lisbon and Casablanca," FEMS Microbiology Ecology, vol. 88, no. 1, pp. 26-37, 2014. 


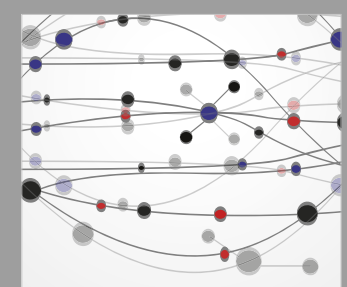

The Scientific World Journal
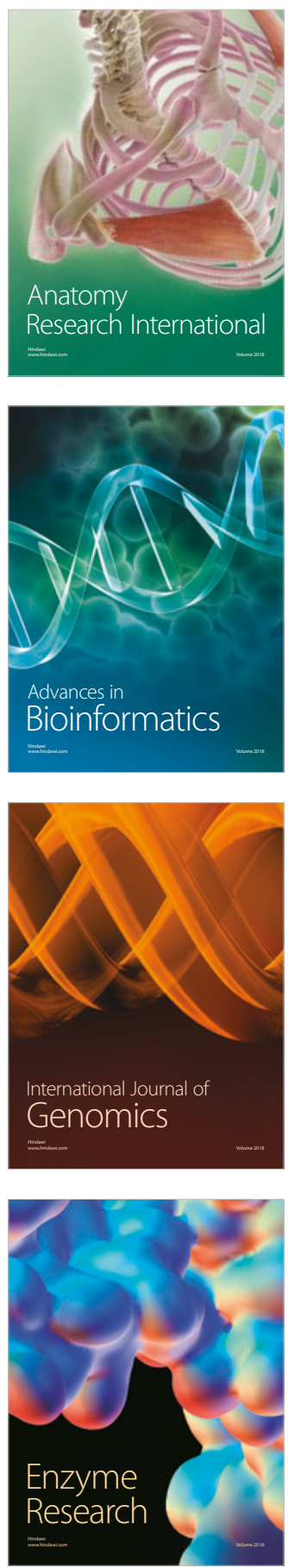
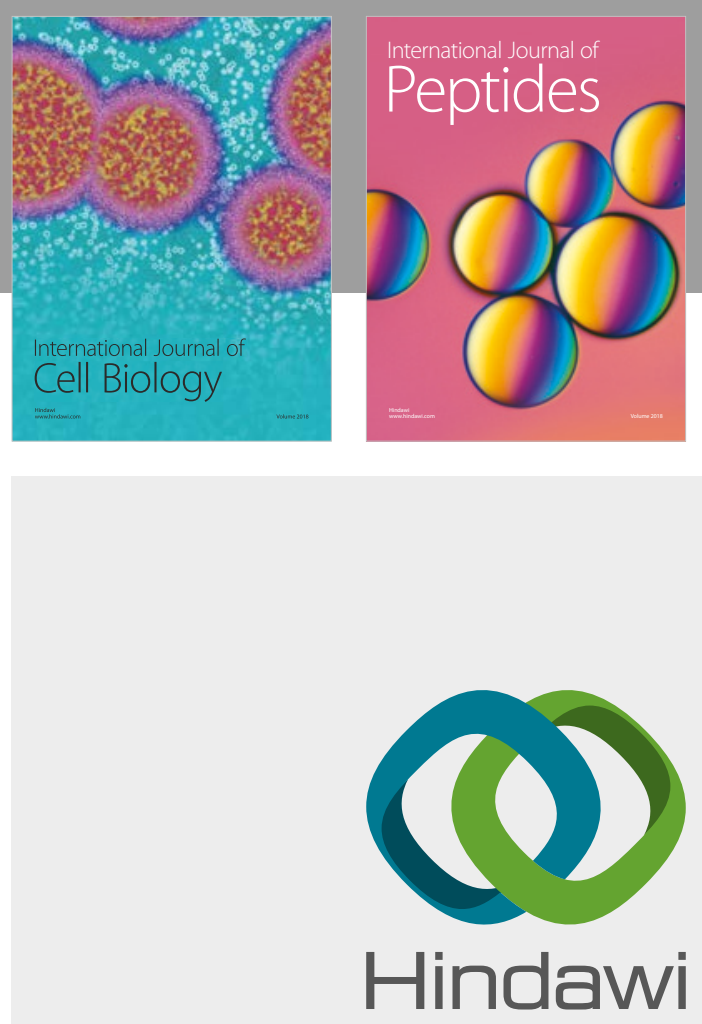

Submit your manuscripts at

www.hindawi.com
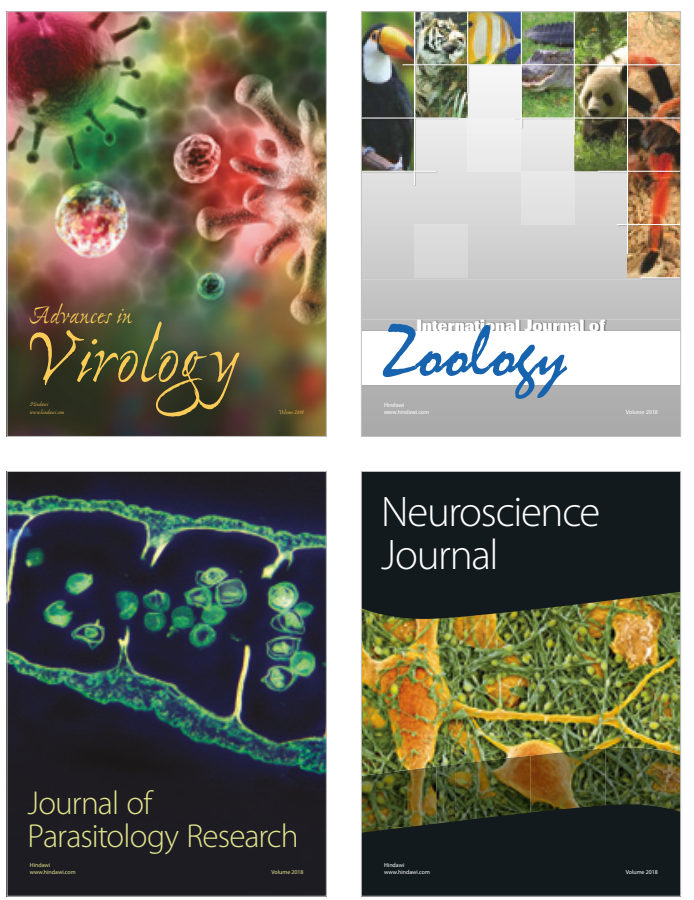
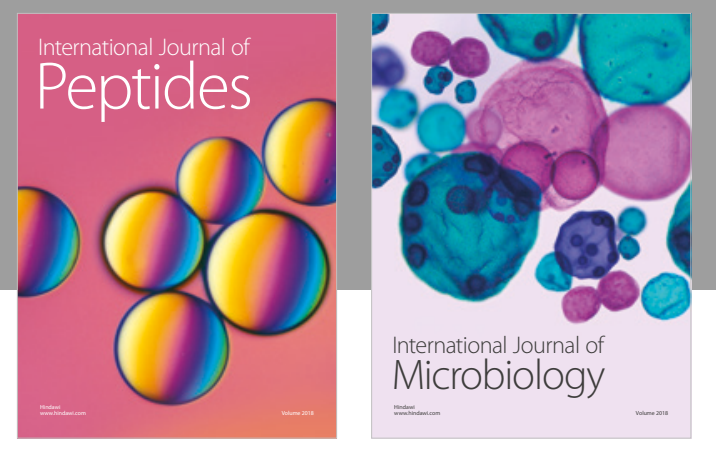

nternational Journal of Microbiology
Journal of
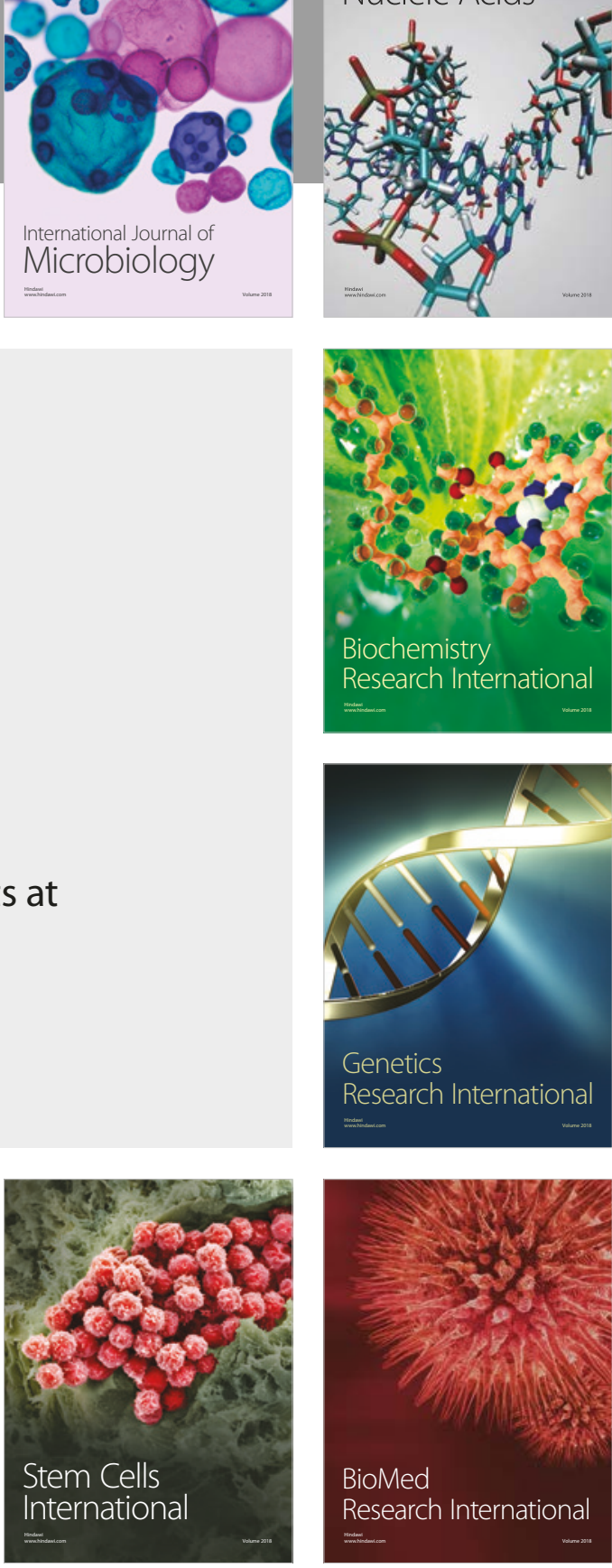
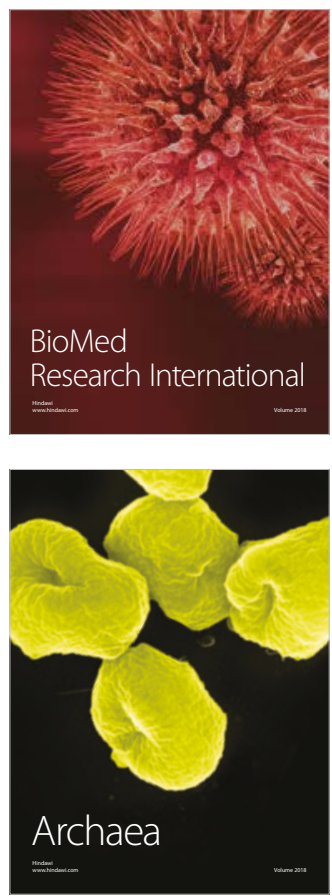